

\title{
SPECTRAL INDUCED POLARIZATION MEASUREMENTS AT THE MAIN IRON INCLINE MINE DUMP NEAR LEADVILLE, COLORADO
}

\author{
by David L. Campbell
}

\section{Open-File Report 01-315 2001}

This report is preliminary and has not been reviewed for conformity with U.S. Geological Survey editorial standards and stratigraphic nomenclature. Any use of trade, product, or firm names is for descriptive purposes only and does not imply endorsement by the U.S. Government.

\section{U.S. DEPARTMENT OF THE INTERIOR U.S. GEOLOGICAL SURVEY}




\title{
SPECTRAL INDUCED POLARIZATION MEASUREMENTS \\ AT THE MAIN IRON INCLINE MINE DUMP \\ NEAR LEADVILLE, COLORADO
}

\author{
by David L. Campbell
}

\section{INTRODUCTION}

As part of a project to investigate formation of acid mine drainage, our USGS team did integrated geological, geochemical, and geophysical studies of eight mine dumps in Colorado and New Mexico. One of these was the Main Iron Incline mine dump, on the west side of Iron Hill, near Leadville, Colorado (fig. 1). The Main Iron Incline mine dump consists of an elongated berm with a level top, trending generally east-west. The mine workings that produced the waste are located further up the side of Iron Hill. The deposit appears to have been constructed by dumping rail cars of mine waste successively off the elongating end of the berm. There probably was a bridge, now gone, over which the waste cars traveled from mine to dump. The berm is about $20 \mathrm{ft}$ high at its uphill end. Its level top is about 15-20 ft wide and over $120 \mathrm{ft}$ long. From there, the berm continues about $60 \mathrm{ft}$ further west, but with its top sloping somewhat downhill. All sides of the berm are at angle of repose.

\section{SUMMARY OF GEOCHEMICAL WORK}

Composite mine dump samples were collected from 8 mine waste piles in Colorado and New Mexico, including the Main Iron Incline mine dump, using a procedure described by Smith and others (2000). Hageman and Briggs (2000) compared waters leached from these samples using two methods, the EPA Method 1312 (U.S. Environmental Protection Agency, 1994) and a modified EPA Method 1312 called the Synthetic Leaching Procedure (SPLP). Leach water from the Main Iron Incline composite sample had $\mathrm{pH}=$ 8.55 when obtained using EPA Method 1312, and $\mathrm{pH}=7.85$ when obtained using SPLP. Smith and others (2000) list amounts of selected metals found in the SPLP leachate water versus particle size fractions for the composite samples. The Main Iron Incline metal contents were low, and $\mathrm{pH}$ values high, in comparison with all but one of the other sampled waste piles.

\section{GEOELECTRICAL FIELD MEASUREMENTS}

On August 3, 1998, spectral induced polarization (SIP) measurements were made along a line centered on the level top of the Main Iron Incline mine dump. A Zonge NT-20 transmitter and GDP-32 receiver were used in an $\mathrm{N}=5$ dipole-dipole configuration with $10 \mathrm{ft}$ dipoles. Resistivity and phase were measured at fundamental frequencies of 0.125 , $0.5,1.0$, and $8.0 \mathrm{~Hz}$, and at the $3^{\text {rd }}, 5^{\text {th }}, 7^{\text {th }}$, and $9^{\text {th }}$ harmonic of each of these fundamental frequencies, yielding 20-point spectra in the frequency interval from 0.128 to $72 \mathrm{~Hz}$.

Fig. 2 shows pseudosections of the measured apparent resistivity and phase at $0.125 \mathrm{~Hz}$, the lowest frequency used. It also shows "3-point phase", an estimate of the DC phase 
value based on an extrapolation of values measured at $0.125,0.375$, and $0.625 \mathrm{~Hz}$. A pseudosection (Sumner, 1976) is a graphical way to show horizontal and vertical variations of measured values along a dipole-dipole survey line. To make one, a horizontal line is drawn showing locations of all electrodes. A line is then drawn from the center of each transmitter dipole, extending down at an angle of $45^{\circ}$ under the receiver dipoles. Observed values are plotted on this line at the intersections of corresponding $45^{\circ}$ lines from the center of each of the receiver dipoles. Typically, the array of observed values that results is then contoured so as to emphasize variations within it. Automatic computer plots of the Main Iron Incline pseudosections, however, showed only a few, uninteresting, contours. Consequently, no contour lines are shown on fig. 2.

Horizontal and vertical variations of the values shown on fig. 2 are minor in comparison with those observed at other mine dumps (for example, Campbell and others, 1998). Average and standard deviation values for apparent resistivity and phase at $0.125 \mathrm{~Hz}$ and for 3-point phase measured at Main Iron Incline mine dump are given in table 1. Based on the minor variations in these properties, as demonstrated by the relatively low standard deviations in table 1, we infer that the material in the Main Iron Incline mine dump is generally uniform in composition.

\section{SPECTRAL MEASUREMENTS}

A 20-point spectrum was measured at each of the 50 pseudosection locations indicated on fig. 2. Except for 8-10 spectra that probably were distorted by electromagnetic coupling with buried metal, the measured spectra were generally flat and featureless. Fig. 3 shows two typical spectra, taken from the middle of the survey line. These spectra are similar to most of the field spectra from the Main Iron Incline mine dump, in that their resistivity values decrease slightly with frequency, whereas their phase values either increase slightly (fig. 3a) or form minor maxima (fig. 3b).

Resistivity and phase spectra were also measured in the USGS Petrophysical Laboratory for the composite sample mentioned above (Anderson and others, 2001). Fig. 4 shows the laboratory spectrum together with the field spectrum taken from fig. 3b. Laboratory and field spectra do not correspond very well. A similar mismatch between laboratory and field spectra was found at the Tucson mine dump (Campbell and Horton, 2000a). Possible reasons for these disparities are discussed by Campbell and Horton (in prep.).

\section{REFERENCES}

Anderson, A.L., Campbell, D.L., and Beanland, Shay, 2001, Laboratory measurements of electrical properties of composite mine dump samples from Colorado and New Mexico: U.S. Geological Survey Open-File Report 01-158, 55 p. http://geology.cr.usgs.gov/pub/open-file-reports/ofr-01-0158

Campbell, D.L., Fitterman, D.V., Hein, A.S., and Jones, D.P., 1998, Spectral induced polarization studies of mine dumps near Silverton, Colorado: Proceedings of the 
Symposium on the Application of Geophysics to Engineering and Environmental Problems, March 23-27, 1998, Chicago, Illinois, p. 761-769.

Campbell, D.L., and Horton, R.J., 2000a, Geoelectrical laboratory and field studies of materials from the Tucson Mine dump near Leadville, Colorado: U.S. Geological Survey Open-file report 00-312.

Campbell, D.L., and Horton, R.J., 2000b, Graphs and tables used to describe electrical measurements of samples of unconsolidated material, USGS Petrophysical Laboratory Denver: U.S. Geological Survey Open-file report 00-377. http://crustal.usgs.gov/minewaste/publications mine.html

Campbell, D.L., and Horton, R.J., in prep., Characterization of mine waste materials using spectral induced polarization methods, in Smith, K.S., ed., planned U.S. Geological Survey Professional Paper.

Hageman, P.L., and Briggs, P.H, 2000, A simple field leach test for rapid screening and quantitative characterization of mine waste dump material on abandoned mine lands: ICARD2000 - Proceedings from the Fifth International Conference on Acid Rock Drainage; Littleton CO, Society for Mining, Metallurgy, and Exploration, Inc., p. 14631475. http://crustal.usgs.gov/minewaste/minewaste pubs.html

Smith, K.S., Ramsey, C.A., and Hageman, P.L., 2000, Sampling strategy for the rapid screen of mine-waste dumps on abandoned mine lands: ICARD2000_Proceedings from the Fifth International Conference on Acid Rock Drainage; Littleton CO, Society for Mining, Metallurgy, and Exploration, Inc., p. 1453-1461. http://crustal.usgs.gov/minewaste/minewaste_pubs.html

Sumner, John S., 1976, Principles of induced polarization for geophysical exploration: New York, Elsevier Scientific Publishing Company, 278 p.

U.S. Environmental Protection Agency, 1994, Test methods for evaluating solid waste, physical/chemical methods (SW-846), $3^{\text {rd }}$ edition, update 2B: Environmental Protection Agency, National Center for Environmental Publications, Cincinnati, OH 45268, telephone 800-553-6847, order number EPASW-846.3.2B. http://www.epa.gov/epaoswer/hazwaste/test/sw846.htm 
Table 1. Averages and estimated standard deviations for SIP properties (fig. 1) measured at the Main Iron Incline mine dump.

\begin{tabular}{|l|l|l|l|l|l|l|}
\hline \multirow{2}{*}{} & \multicolumn{3}{|l|}{ App. Resistivity (ohm-m) } & \multicolumn{2}{l|}{$0.125 \mathrm{~Hz}$ Phase(mRad) } & 3-point Phase (mRad) \\
\cline { 2 - 7 } & Average & Std. Dev. & Average & Std. Dev. & Average & Std. Dev. \\
\hline $\mathrm{N}=1$ & 256.26 & 38.32 & 15.56 & 1.04 & 14.98 & 1.26 \\
\hline $\mathrm{N}=2$ & 281.06 & 23.32 & 16.35 & 1.45 & 16.49 & 2.24 \\
\hline $\mathrm{N}=3$ & 284.99 & 37.25 & 16.36 & 1.71 & 16.08 & 1.69 \\
\hline $\mathrm{N}=4$ & 287.21 & 40.14 & 16.21 & 1.60 & 15.94 & 1.69 \\
\hline $\mathrm{N}=5$ & 286.06 & 41.81 & 16.71 & 1.43 & 16.39 & 0.99 \\
\hline All N's & 278.04 & 36.77 & 16.19 & 1.44 & 15.93 & 1.69 \\
\hline
\end{tabular}

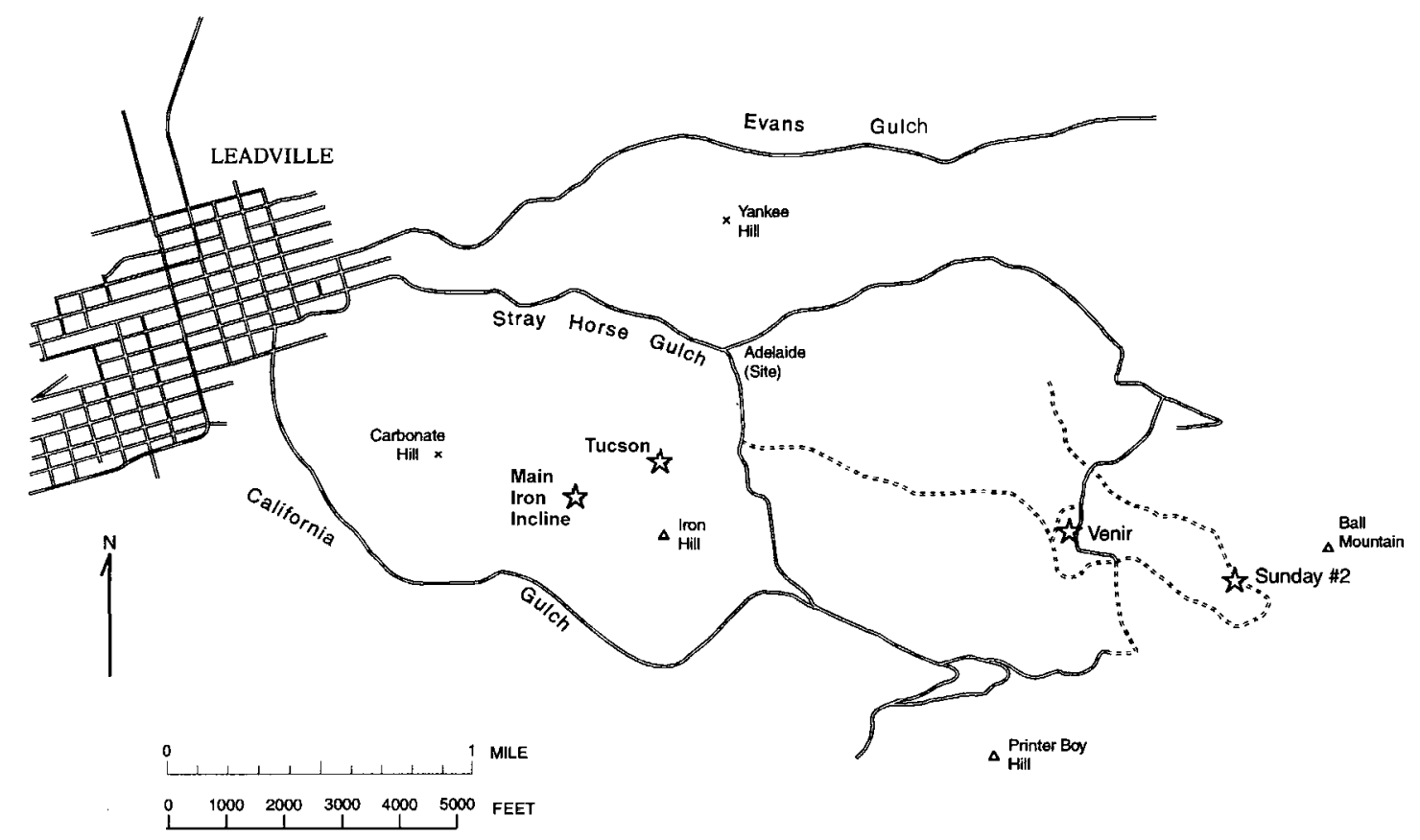

Figure 1. Outline map of mining areas east of Leadville, Colorado. Large stars indicate mine dumps our USGS team has studied. The Main Iron Incline mine dump is in the left-center of the map. 


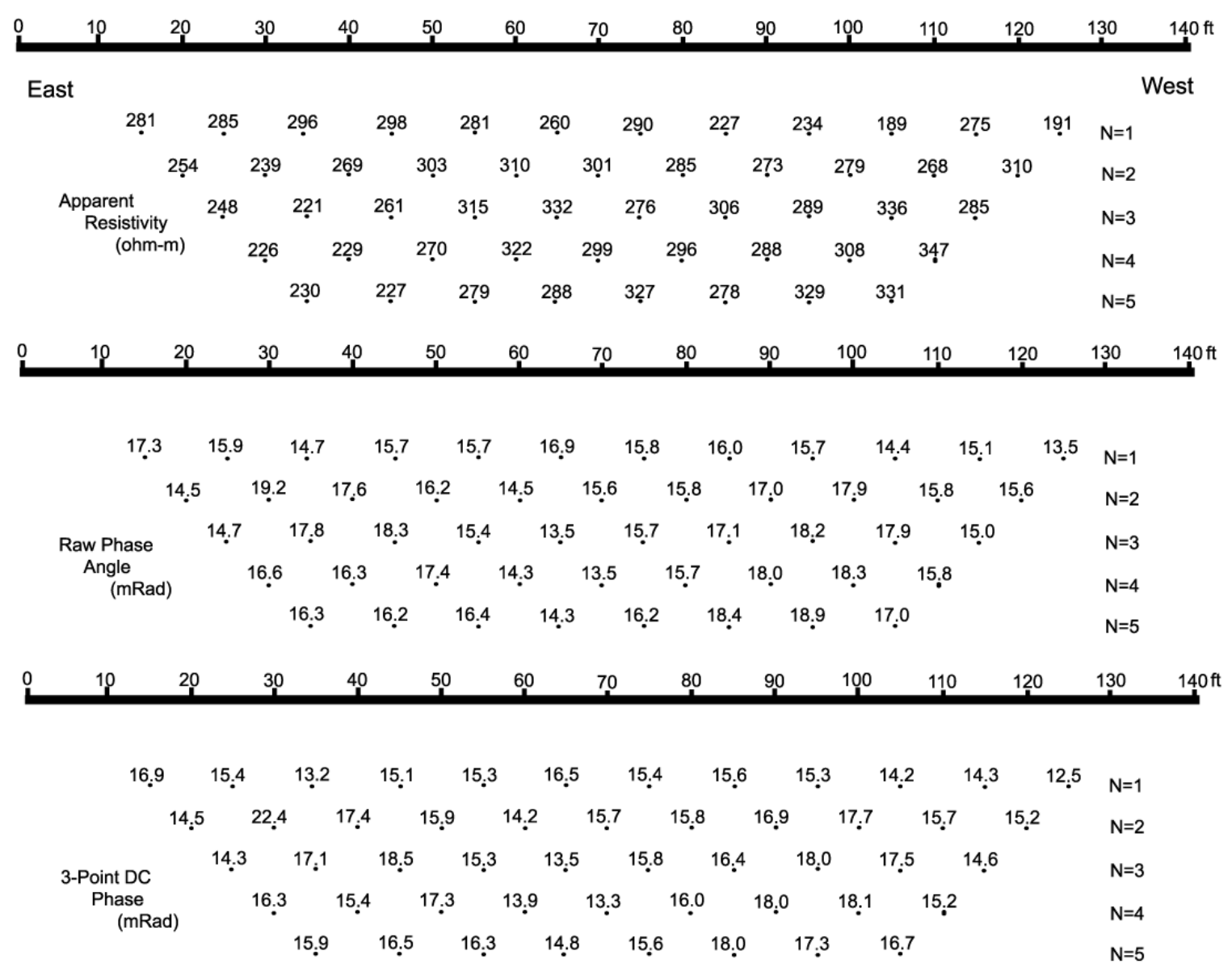

Figure 2. Pseudosections showing apparent resistivity at $0.125 \mathrm{~Hz}$ (top), Raw Phase (phase at $0.125 \mathrm{~Hz}$ ), and 3-point phase at Main Iron Incline mine dump. 

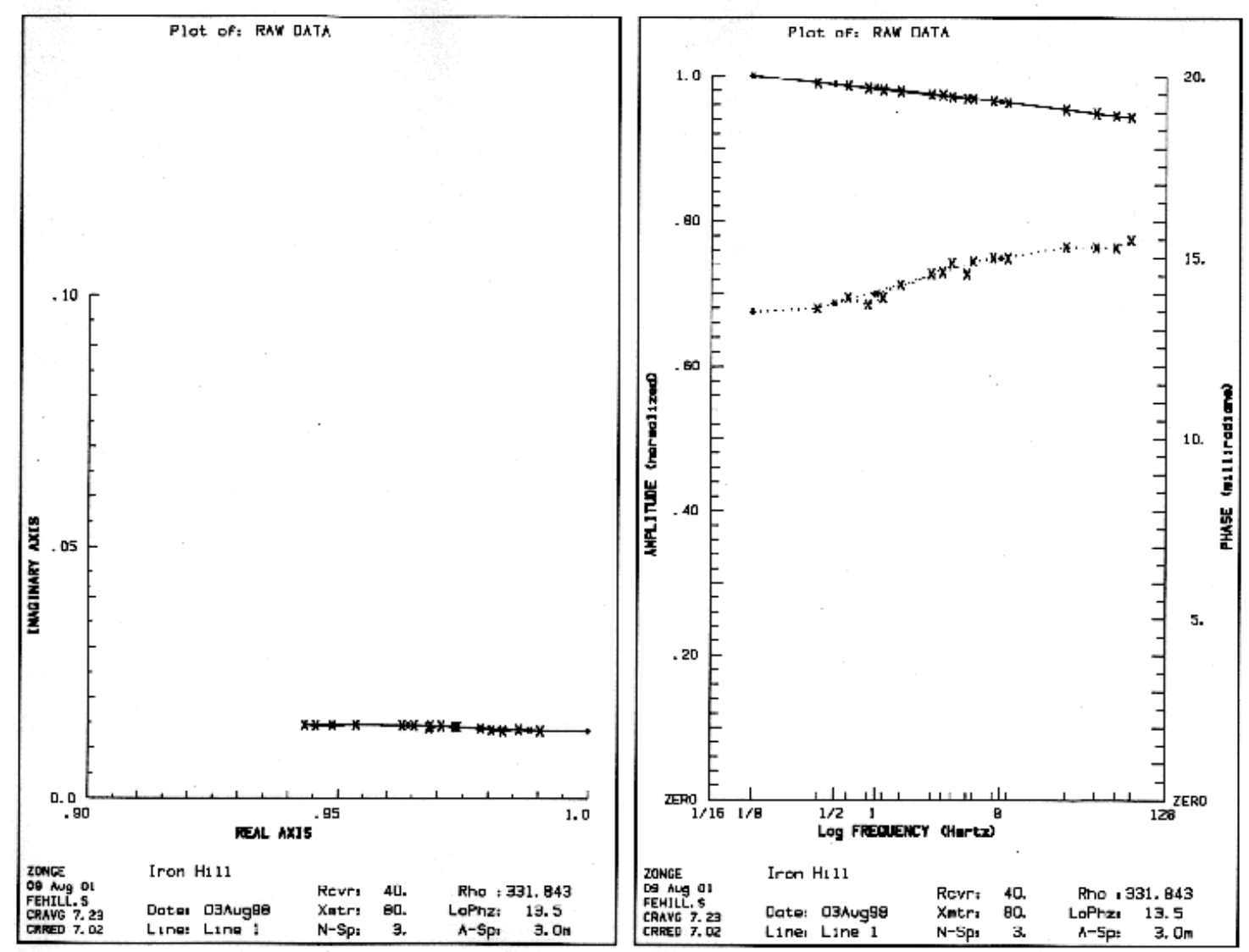

Figure 3a. Spectra for transmitter dipole at coordinates $80-90 \mathrm{ft}$ and receiver dipole at 40-50 ft. Data is plotted on left panel as an Argand diagram, and on right panel versus frequency. 

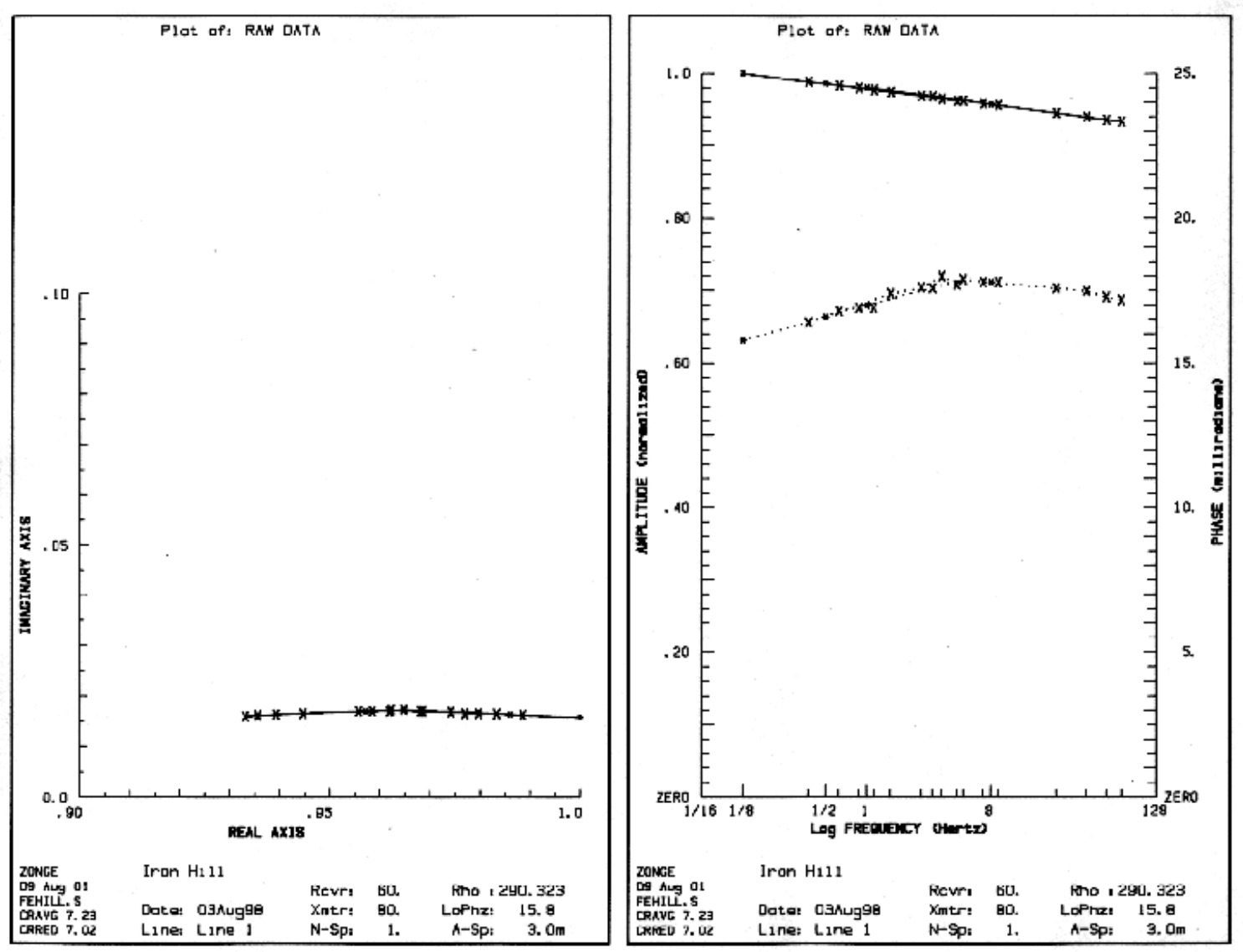

Figure 3b. Spectra for transmitter dipole at coordinates 80-90 ft and receiver dipole at 60-70 ft. Data is plotted on left panel as an Argand diagram, and on right panel versus frequency. 
Main Iron Incline Mine Composite with 5\% DIW

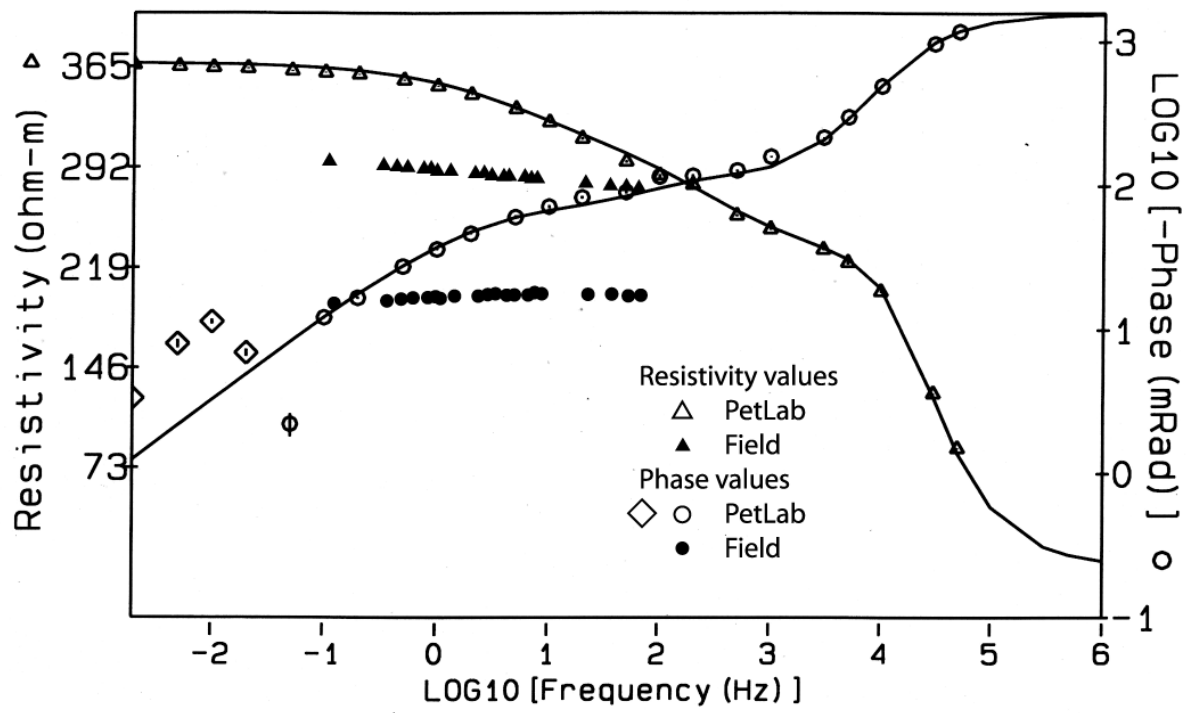

Figure 4. Spectra of material from Main Iron Incline mine dump, as measured in the laboratory (PetLab) and field. The sample measured in PetLab was the composite mine dump sample, rehydrated with de-ionized water to $5 \%$ water content. Diamond symbols represent positive phase values, circles represent negative phase values. Solid line is Cole-Cole fit (see Campbell and Horton, 2000b) to PetLab values. 